\title{
BANCADA SINDICAL, POLÍTICA PREVIDENCIÁRIA E PROCESSO DECISÓRIO NO GOVERNO DILMA*
}

\section{Sidney Jard da Silva}

Universidade Federal do ABC (UFABC), São Bernardo do Campo - SP, Brasil. E-mail: sidney.jard@ufabc.edu.br.

DOI: $10.1590 / 339810 / 2018$

\section{Introdução}

Entre o final da década de 1970 e início dos anos de 1980, o novo sindicalismo se transformou em uma das principais forças políticas e sociais do

* Sou grato aos editores e pareceristas da RBCS pelas relevantes contribuiçóes para o aprimoramento deste artigo. Estendo meus agradecimentos a Alexandre Ferraz, Antónia Mota, Deise Recoaro, Elísio Estanque, Gabriela Lotta, Hermes Costa, Maria Chaves Jardim e Renata Bichir pelo incentivo em diferentes momentos em que versôes anteriores deste trabalho foram apresentadas. À Karen Fonseca - integrante do grupo de pesquisa Política, Políticas Públicas e Ação Coletiva (3 PAC) - agradeço a imprescindível colaboraçáo na análise discursiva dos atores sindicais. Por fim, sou imensamente grato ao Centro de Estudos Sociais - Universidade de Coimbra (CES-UC) pela generosa estadia durante meu estágio de pós-doutoramento. A pesquisa contou ainda com o auxílio financeiro do Conselho Nacional de Desenvolvimento Científico e Tecnológico (CNPq).

Artigo recebido em 03/02/2017

Aprovado em 16/10/2017 país (Jácome Rodrigues, 1999; Veras, Bridi e Ferraz, 2014). Nesse mesmo período foram criadas duas das principais instituições representativas dos trabalhadores brasileiros: o Partido dos Trabalhadores (PT) e a Central Única dos Trabalhadores (CUT). Duas décadas depois, no início dos anos de 2000, o ex-líder sindical Luiz Inácio Lula da Silva chegou à Presidência da República e exerceu o poder por duas vezes consecutivas: 2003-2006 e 2007-2010.

Não obstante essa trajetória política bem-sucedida, são relativamente escassos os trabalhos dedicados à atuação partidária das lideranças sindicais no Brasil, especialmente no que se refere aos parlamentares sindicalistas (deputados e senadores) no Congresso Nacional. ${ }^{1}$

Este trabalho pretende suprir parte dessa lacuna nos estudos sobre sindicalismo e políticas públicas. Seu objetivo principal é realizar uma análise da atuação dos parlamentares sindicalistas na política previdenciária do primeiro mandato do governo de 
Dilma Vana Rousseff (2011-2014). Seu objeto de estudo é a participação da bancada sindical na criação da Fundação de Previdência Complementar do Servidor Público Federal (Funpresp).

Costa (2011), ao rever as principais abordagens teóricas do sindicalismo, destaca que existem pelo menos três classificaçóes distintas dos sindicatos como objeto de estudo: 1) os sindicatos como parte dos movimentos sociais; 2) os sindicatos como instituiçóes do mercado de trabalho; 3) os sindicatos como grupo de interesses. $\mathrm{Na}$ esteira de Visser (1995), o mesmo autor observa que a primeira classificaçáo, o sindicalismo com parte dos movimentos sociais, tende a ser o objeto de estudo privilegiado de historiadores e sociólogos. Já entre os economistas predomina a visão dos sindicatos enquanto instituições do mercado de trabalho. Por fim, entre os cientistas políticos prevalecem os estudos sobre os sindicatos enquanto grupo de interesses, com destaque para sua interação com o sistema político partidário.

Ao problematizar as múltiplas formas de pressão do sindicalismo sobre o processo decisório das políticas públicas, este trabalho filia-se à terceira abordagem teórica anteriormente indicada. Argumenta que a compreensão da participação sindical na política previdenciária é incompleta se não considera a intervenção direta dos parlamentares sindicalistas no trâmite legislativo dos projetos que têm como objetivo promover alteraçóes na previdência social. Portanto, parte do pressuposto de que a bancada sindical é um ator importante no que se refere ao debate legislativo da reforma do sistema previdenciário.

Desde a promulgação da Constituição de 1988, parlamentares sindicalistas ocupam papel de destaque nas comissóes legislativas que tratam de temas relativos às políticas sociais, especialmente trabalhistas e previdenciárias (Diniz, 1999; Noronha, 1999). ${ }^{2}$ Nas últimas duas décadas, a bancada sindical também cumpriu papel importante no debate legislativo das principais propostas de mudança do sistema previdenciário brasileiro encaminhadas ao Congresso Nacional (Jard da Silva, 2013; 2007).

Assim, o problema de pesquisa que orienta este trabalho é formulado a partir das seguintes questôes: em situaçóes político-institucionais em que um governo considerado aliado envia ao Congres- so Nacional projetos que contrariam interesses de importante setores do movimento sindical, qual é a posição predominante no bloco sindicalista? Defender as demandas das suas bases de representação social ou seguir a orientação do partido e/ou coalizão partidária da qual faz parte?

Como veremos ao longo deste trabalho, nem sempre a posição da bancada sindical corresponde exatamente à posição das entidades sindicais no debate público sobre a reforma da previdência. As regras do jogo do processo decisório, isto é, os arranjos político-institucionais no interior do Legislativo, limitam as possibilidades de reação e resistência dos deputados e senadores sindicalistas às propostas de mudança da política previdenciária.

Seguindo a classificação do Departamento Intersindical de Assessoria Parlamentar (Diap, 2002), defino como integrantes da bancada sindical os deputados e senadores que foram militantes ou dirigentes sindicais e que, depois de eleitos, mantiveram vínculos com as suas categorias profissionais e entidades sindicais. A definição proposta é particularmente útil porque se trata da identificação de parlamentares (deputados e senadores) reconhecidos como aliados do movimento sindical pelo principal órgão de assessoria parlamentar das entidades sindicais (Santos, 2007). Também apresenta a vantagem de identificar os parlamentares que mantiveram vínculos com as suas categorias profissionais de origem, mesmo que, antes de eleitos para o Congresso Nacional, tivessem assumido cargos em outras esferas políticas (vereadores, legisladores estaduais, secretários, ministros etc.)

A análise dos discursos dos parlamentares sindicalistas nos principais momentos do processo decisório da criação da Funpresp adotou como referencial teórico e metodológico a análise de discurso (Cilla e Jard da Silva, 2015). Nessa parte do trabalho, o principal objetivo foi identificar categorias discursivas favoráveis e contrárias à criação do regime de previdência complementar dos servidores públicos federais no interior da bancada sindical (Idem, 2016).

Por fim, seguindo Figueiredo e Limongi (1998, p. 80), o critério adotado para definir a "disciplina" do bloco sindicalista nas principais votaçóes do Projeto de Lei n. 1992, de 11 de setembro de 2007 (PL 
n. 1992/2007), levou em consideração o número de deputados e senadores de origem sindical "a votar em acordo com as pretensôes governamentais sobre o total dos que votaram". Autores como Melo e Anastasia (2006, p. 316) preferem adotar como critério o número de parlamentares "sobre a bancada e não apenas sobre os presentes". Essa última definição seria particularmente interessante para aferir o grau de fidelidade partidária em matérias que demandam maioria qualificada para sua aprovação, quando a coesão e a disciplina da base governista são mais exigidas. ${ }^{3}$ No entanto, como a aprovação da Funpresp exigia apenas maioria absoluta no quorum para votação e maioria simples no quorum para aprovaçáo, os critérios definidos por Figueiredo e Limongi (1998) mostraram-se suficientes e adequados para este trabalho.

$\mathrm{O}$ artigo está dividido em seis seções. Além da "Introdução", na primeira seção retomo o trâmite legislativo do PL n. 1992/2007, com especial destaque para as "regras do jogo" da aprovação de um Projeto de Lei Ordinária. Na segunda, realizo uma "radiografia" da bancada sindical no Congresso Nacional, com foco na localização dos parlamentares sindicalistas (deputados e senadores) em relação aos partidos que compóem a base do governo no parlamento. $\mathrm{Na}$ terceira, analiso o discurso sindical no debate legislativo da criação da Funpresp. $\mathrm{Na}$ quarta seção, apresento o padrão de votação predominante no bloco sindicalista nas principais fases de tramitação do PL n. 1992/2007. Por fim, nas "Considerações finais", apresento os achados de pesquisa mais relevantes.
O trâmite legislativo ${ }^{4}$

Há relativo consenso entre os estudiosos de que as dificuldades encontradas pelos governos em aprovar mudanças nas políticas públicas são explicadas, fundamentalmente, pela natureza das medidas propostas e pelas regras que regulam o processo decisório. Medidas impopulares, que impóem custos concentrados e benefícios difusos, sujeitas à processos decisórios de grande exposição, nos quais seus defensores são facilmente identificados, são consideradas "politicamente inviáveis" (Arnold, 1998; 1990; Figueiredo e Limongi, 1999; 1998; Pierson, 1997).

Nessa perspectiva, tanto as regras do processo decisório quanto a natureza das reformas previdenciárias favoreceriam a atuaçáo de grupos de interesses atingidos negativamente pelas propostas de mudança da política pública. Os sindicatos como principais entidades representativas dos trabalhadores atingidos pela reforma do sistema previdenciário encontrariam um cenário político institucional favorável à resistência (Jard da Silva, 2013; 2007).

Um PL de autoria do Executivo deve iniciar sua tramitação obrigatoriamente pela Câmara dos Deputados (Jard da Silva e Diniz, 2009). Em seu curso ordinário, a matéria precisa ser apreciada e aprovada separadamente na Câmara e no Senado, antes de seguir para a sanção (ou veto) presidencial. Caso haja alteração na última casa, o projeto retorna para a primeira.

Quadro 1

Regras Institucionais para Tomadas de Decisóes Sobre PLs

\begin{tabular}{ll}
\hline Iniciativa & Não exclusiva \\
\hline Processo legislativo & Bicameral \\
\hline Quorum para votaçáo & Maioria absoluta \\
\hline Quorum para aprovaçáo & Maioria simples \\
\hline Turnos de votaçáo & Um (em cada casa) \\
\hline Tipo de votaçáo & Nominal ou simbólica \\
\hline Poder de veto do Executivo & Existente \\
\hline
\end{tabular}

Fonte: Elaboração própria com base em Figueiredo e Limongi (1998; 1996). 
$\mathrm{Na}$ criação da previdência complementar dos servidores públicos federais, por se tratar de um Projeto de Lei Ordinária e náo de uma Proposta de Emenda Constitucional, o governo de Dilma Vana Rousseff enfrentou menos obstáculos político-institucionais do que aqueles enfrentados pelos seus antecessores, Luiz Inácio Lula da Silva e Fernando Henrique Cardoso.

Em termos de política previdenciária, o governo Dilma apenas deu continuidade às mudanças já iniciadas nos governos FHC e Lula. O caminho para a criação da Funpresp, sem a necessidade de mudanças constitucionais, já tinha sido preparado nas reformas previdenciárias dos governos anteriores. Assim, no sentido estrito do termo, a criação do novo fundo não representou uma reformado sistema previdenciário, embora tenha promovido importantes mudanças no regime próprio de previdência do funcionalismo federal.

$\mathrm{O}$ arcabouço legal do mercado de fundos de pensão para os trabalhadores das empresas privadas e estatais foi regulamentado no Brasil no final dos anos de 1970. Desde então, as entidades fechadas de previdência complementar assumiram crescente importância nas estratégias econômicas e políticas de diferentes governos (Grun, 2005; 2003). No início dos anos de 1990, os fundos de pensão se tornaram um dos atores centrais no processo de privatizaçóes das empresas estatais brasileiras. No final da primeira década dos anos de 2000 , foram igualmente importantes no desenvolvimento de uma política econômica anticíclica com o objetivo de amenizar os impactos da crise financeira internacional sobre o país (Jardim, 2013a).

Ainda que existam grandes divergências no movimento sindical sobre a expansão do mercado de previdência complementar, nas últimas décadas, as principais centrais sindicais do país - notadamente CUT e Força Sindical (FS) - investiram significativos recursos materiais e humanos na formação de gestores de fundos de pensão. Essa aproximação entre sindicalistas e mercado de previdência privada começou durante o governo de Fernando Henrique Cardoso e se aprofundou nos governos de Luiz Inácio Lula da Silva e de Dilma Vana Rousseff (Jard da Silva, 2014).

No interior do Congresso Nacional, mais do que por uma clivagem político-ideológica, a cria- ção da Funpresp foi marcada pelo debate entre os parlamentares sindicalistas vinculados aos trabalhadores do serviço público (regime próprio), de um lado, e os parlamentares sindicalistas vinculados à trabalhadores de empresas estatais e privadas (regime geral), do outro. Entre os primeiros estavam as principais vozes contrárias à criação da previdência complementar para os servidores públicos; entre os últimos, os principais defensores da expansão dos fundos de pensão no setor público (Cilla e Jard da Silva, 2015).

O PL n. 1992/2007 foi apresentado no início do segundo mandato do governo Lula, após a implementação de sucessivas reformas constitucionais do sistema previdenciário. A partir da sua criação, os servidores públicos federais passaram a estar submetidos ao mesmo teto de pagamento de benefícios dos trabalhadores do setor privado, isto é, o limite do Instituto Nacional do Seguro Social (INSS). A principal motivação para essa homogeneização dos tetos previdenciários, tal como ocorrera nos governos anteriores, teria sido a busca do equilíbrio fiscal e atuarial do regime próprio de previdência.

Aparentemente, essa medida atingiria apenas os novos servidores do serviço público federal. No entanto, no curto prazo, como bem demonstrou Rangel (2013), a criação da Funpresp provocaria novas pressóes por mudanças nos benefícios previdenciários dos atuais servidores, haja vista que, ao limitar o teto dos benefícios, a medida também limitaria o teto de contribuição dos novos ingressantes no funcionalismo federal. 5 Essa preocupação foi evidenciada nas palavras da então vice-presidente do Sindicato dos Servidores do Poder Legislativo Federal e do Tribunal de Contas da Uniāo (Sindilegis), Luciene Pereira, logo após a aprovação da Funpresp:

O regime próprio não vai ter receitas suficientes e vai ter um aumento das aposentadorias e pensōes. Trinta e cinco anos é um prazo muito longo para lançar os titulares dos poderes e órgãos a uma situação de fragilidade fiscal. $\mathrm{O}$ Brasil vai ter que aumentar o limite da lei de responsabilidade fiscal para poder aumentar o número de servidores. Ao longo desses 35 anos [de transição entre os regimes] haverá um aumento significativo das aposentadorias dos 
servidores que estáo na ativa e as receitas do regime próprio vão ter uma redução. (Agência Brasil, 29 mar. 2012)

Náo por acaso, no Congresso Nacional, o principal bloco de resistência à criação da Funpresp foram os parlamentares vinculados aos servidores públicos ativos e inativos da Uniáo, importante base social da CUT e do PT. Por outro lado, assim como ocorrera no governo do presidente Luiz Inácio Lula da Silva, a presidente Dilma Vana Rousseff pôde contar com o apoio de parte dos votos dos partidos de oposição - Partido da Social Democracia Brasileira (PSDB) e DEM (Democratas) - que sempre defenderam reformas mais profunda no sistema previdenciário brasileiro.

Neste ponto, cabe destacar que a administração Dilma Rousseff adotou o mesmo padráo abrangente de construção de apoio partidário adotado pelos seus antecessores no período pós-democratizaçáo. Em seu primeiro ano de mandato, a base governista contou com a participação de oito partidos - PT, Partido Comunista do Brasil (PCdoB), Partido Democrático Trabalhista (PDT), Partido Socialista Brasileiro (PSB), Partido do Movimento Democrá- tico Brasileiro (PMDB), Partido Progressista (PP), Partido da República (PR) e Partido Republicano Brasileiro (PRB) - que juntos ocupavam 334 cadeiras $(65,11 \%)$ da Câmara dos Deputados.

O governo Dilma reunia, com folga, muito mais do que os votos necessários para a aprovação das proposiçóes do Executivo enviadas ao Legislativo. Como no caso de Projetos de Lei Ordinária, precisava da maioria absoluta apenas na verificação do quorum e da maioria simples nas votaçóes. Contudo, veremos a seguir que a aritmética dos votos é condição necessária, mas não suficiente para garantir a aprovação de matérias legislativas.

Muito embora a base governista contasse com maioria numérica para aprovar suas propostas no Congresso Nacional, no processo decisório da mudança das políticas públicas, essa maioria é construída em um árduo processo de negociação da natureza e da visibilidade das mudanças propostas, as quais podem aumentar ou diminuir o grau de apoio da base parlamentar do governo, bem como a resistência da base oposicionista (Palermo, 2016; 2009; Silva, 2014).

Nesse sentido, buscar o apoio de bancadas suprapartidárias que estejam dispostas a compartilhar

Figura 1

Composiçáo Partidária da Câmara dos Deputados

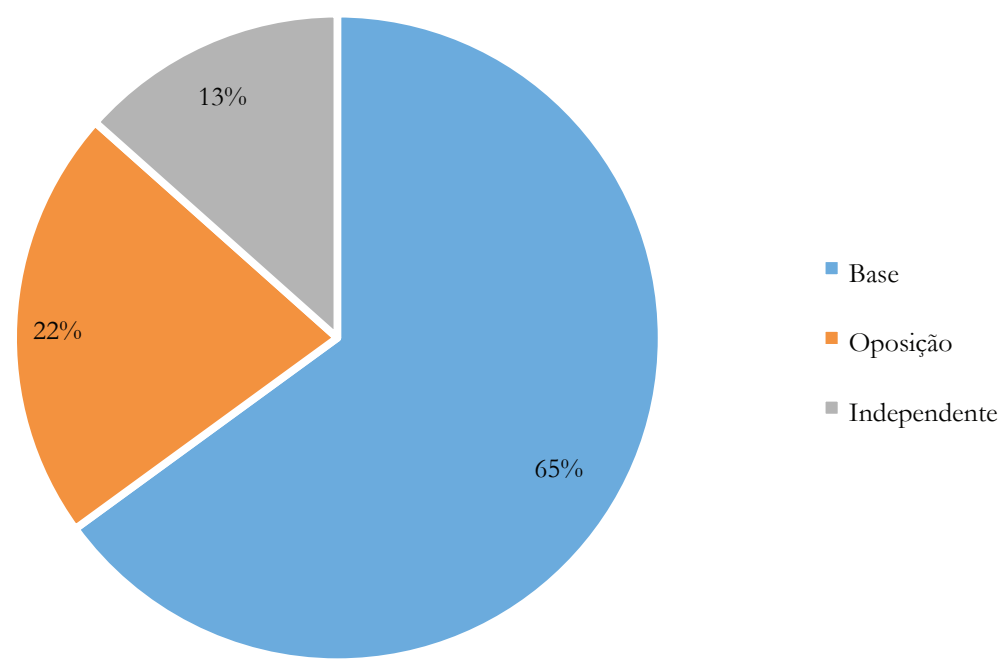

Fonte: Elaboração própria com base em Carreirão (2014), Diap (2014); Oposição e Independente: Diap (2014). 
o ônus de políticas impopulares com o Executivo é fundamental na relaçáo com o Legislativo. De fato, o apoio de aliados, mesmo de grupos relativamente pequenos, como era o caso da bancada sindical no parlamento, é extremamente importante no processo de legitimação das propostas do governo.

O PL n. 1992/2007 tramitou no Congresso Nacional por quase cinco anos. Na Câmara dos deputados foram quatro anos e meio, os seis meses restantes no Senado Federal (Quadro 2). Parafraseando Figueiredo e Limongi (1998, p. 71), o tempo, porém, não revela as diferenças, que são marcantes, no padrão decisório de cada uma das casas.

$\mathrm{Na}$ Câmara, em apenas uma comissão legislativa, a Comissão de Trabalho, de Administração e Serviço Público (CTASP), a matéria permaneceu por mais de quatro anos. Já no Senado, a tramitação em três comissóes legislativas - Comissão de Assuntos Sociais (CAS), Comissão de Assuntos Econômicos (CAE) e Comissão de Constituição, Justiça e Cidadania (CCJ) - levou menos de três meses.

No que se refere à apreciação no plenário das duas casas, vale ressaltar que, enquanto na Câmara dos Deputados a votação do PL n. 1992/2007 foi nominal, no Senado foi utilizado o instrumento de votação simbólica para a aprovação da matéria. $\mathrm{Na}$ casa revisora, a principal tarefa da base governista foi evitar que o projeto apoiado pelo Executivo sofresse mudanças que o levassem a ser novamente apreciado pela primeira casa. Assim, o papel dos senadores da base governista foi rejeitar emendas e recursos que poderiam levar o projeto apoiado pelo Executivo novamente para a Câmara dos Deputados.

Conforme já registrado amplamente por estudiosos do processo decisório, o Senado cumpre papel de fundamental importância no sentido de reconstituir pontos importantes de proposiçóes alteradas pela Câmara, como ocorreu na reforma previdenciária do governo FHC (Melo e Anastasia, 2006; Figueiredo e Limongi, 1998), ou de acelerar o processo de sanção de PLs avalizados pelo Executivo, como ocorreu no governo Lula (Jard da Silva, 2016).

No caso específico da lei de criação da Funpresp, o Senado cumpriu novamente o papel de acelerar e preparar o projeto para a sanção presidencial, mais do que fazer uma efetiva revisão do

Quadro 2

Sumário da Tramitaçáo do PL n. 1992/2007

\begin{tabular}{lll}
\hline Início & Tramitaçáo & Duraçáo (em dias) \\
\hline Câmara & & \\
\hline $5 / 9 / 2007$ & Executivo envia o Projeto & 6 \\
\hline $11 / 9 / 2007$ & Apresentação do Projeto & 6 \\
\hline $17 / 9 / 2007$ & Apreciaçáo CTASP & 1.444 \\
\hline $6 / 9 / 2011$ & Apreciação CSSF & 99 \\
\hline $3 / 10 / 2011$ & Plenário & 148 \\
\hline $11 / 10 / 2011$ & Apreciaçáo CFT & 64 \\
\hline $11 / 10 / 2011$ & Apreciaçáo CCJC & 64 \\
\hline Senado & & \\
\hline $2 / 3 / 2012$ & Leitura do Projeto & 1 \\
\hline $2 / 3 / 2012$ & Apreciaçáo CAS & 26 \\
\hline $2 / 3 / 2012$ & Apreciaçáo CAE & 25 \\
\hline $2 / 3 / 2012$ & Apreciação CCJ & 26 \\
\hline $28 / 3 / 2012$ & Discussão em turno único & 1 \\
\hline
\end{tabular}

Fonte: Elaboração própria com base em dados do Portal da Câmara dos Deputados e do Site do Senado Federal. 
projeto aprovado na Câmara dos Deputados, como seria teoricamente esperado de uma casa revisora. ${ }^{6}$

A análise da tramitação do PL n. 1992/2007 evidencia a diferença no padrão decisório na Câmara e no Senado, bem como aponta o momento em que o Executivo efetivamente se empenha pela aprovação do projeto, no primeiro ano de mandato do governo de Dilma Rousseff.

Conforme registrado no Quadro 2, o PL de criação da Funpresp foi lento na sua primeira fase de apreciação pela Câmara dos Deputados. Apenas na CTASP, o projeto permaneceu por mais de quatro anos. Em outras palavras, ficou nessa comissão até o final do segundo mandato do governo Lula e início do governo Dilma.

Já na legislatura de 2011-2015, a matéria foi apreciada por três comissões, Comissão de Seguridade Social e Família (CSSF), Comissão de Finanças e Tributação (CFT) e Comissão de Constituição e Justiça e de Cidadania (CCJC) em pouco mais de três meses. Destaca-se, neste ponto, a solicitação de urgência apresentada pelo Executivo. ${ }^{7}$ Ainda assim, no plenário da Câmara foram necessários mais cinco meses para a aprovação do PL n. 1992/2007. No Senado, o trâmite do projeto foi mais célere, menos de um mês, incluindo apreciação das comissões, discussão e votação. Como notado anteriormente, coube à casa revisora apenas ratificar o que havia sido aprovado na Câmara dos Deputados, sem promover alteraçóes que pudessem levar o projeto novamente para apreciação da primeira casa.

Por fim, cumpre apontar que, não obstante a forte oposição dos servidores públicos e de suas entidades representativas (associações e sindicatos), durante todo o trâmite legislativo do PL n. 1992/2007, a bancada sindical seguiu de forma disciplinada a orientação da base governista, da qual a ampla maioria dos seus integrantes fazia parte, votando favoravelmente ao projeto de criação da Funpresp. É o que veremos nas próximas seçôes deste artigo.

\section{A bancada sindical}

A expansão da democracia representativa, nas principais economias ocidentais, foi acompanhada pela ascensão assimétrica de certos grupos sociocupacionais ao Poder Legislativo. Em todo o mundo, o recrutamento da classe política é realizado a partir de um número relativamente pequeno de profissóes e ocupações, entre os quais se destacam administradores, advogados, empresários, funcionários públicos, médicos, professores etc. (Codato, Ferreira e Costa, 2015; Martins Rodrigues, 2009a; 2009b; Santos, 1997)

Entre as categorias sociocupacionais dos empregados assalariados, os sindicatos constituem um dos principais instrumentos para a organização e financiamento de campanhas eleitorais bem-sucedidas. Além de proporcionar acesso a uma base eleitoral com preferências relativamente homogêneas, principalmente no que se refere às demandas socioeconômicas, as entidades sindicais também proporcionam recursos materiais e humanos que permitem a ampliação do eleitorado para além da própria base. $^{8}$

Martins Rodrigues (2002, p. 35) observa que a presença de sindicalistas nas bancadas partidárias também é um bom "indicador de disposições políticas e ideológicas mais para a esquerda” dos partidos políticos. No Brasil, por exemplo, ao longo dos últimos vinte anos, a grande maioria dos deputados e senadores sindicalistas estiveram presentes nos partidos de esquerda, a sua imensa maioria no PT. Entre os partidos de centro-direita e de direita, por sua vez, a participação de políticos originários do movimento sindical tem sido residual.

A presente pesquisa fornece dados e informaçóes sobre as características institucionais do trâmite legislativo e da disciplina partidária no interior do Congresso Nacional que corroboram os achados de Leôncio Martins Rodrigues sobre a relação entre composição socioeconômica e perfil político ideológico do Legislativo brasileiro. No entanto, ressalva que, em situações político-institucionais nas quais há divergências entre as demandas da sua base de representação social e a orientação das lideranças da coalização partidária da qual fazem parte, os parlamentares sindicalistas tendem a seguir a orientação destas últimas.

Neste ponto, é importante mencionar as imbricadas relaçooes entre sindicatos e partidos políticos no Brasil. Como bem observa Machado Ro- 
drigues (2015), praticamente todas as principais centrais sindicais brasileiras possuem vínculos orgânicos ou inorgânicos com partidos políticos. De acordo com esse autor, teríamos as seguintes filiaçóes orgânicas: CUT com o PT; Central dos Trabalhadores e Trabalhadoras do Brasil (CTB) com o PCdoB e o PSB; Central Geral dos Trabalhadores do Brasil (CGTB) com o Partido Pátria Livre (PPL); Intersindical com o Psol; Central Sindical e Popular (CSP-Conlutas) com o Partido Socialista dos Trabalhadores Unificado (PSTU). Por sua vez, as filiações inorgânicas seriam: FS com o PSDB e o Solidariedade (SD); Uniāo Geral dos Trabalhadores (UGT) com o Partido Popular Socialista (PPS), o Partido Trabalhista Brasileiro (PTB) e o Partido Social Democrático (PSD); Central dos Sindicatos Brasileiros (CSB) com o PMDB e o PDT; Nova Central Sindical de Trabalhadores (NCTS) com o PDT e o PSDB. ${ }^{?}$

Sem entrar em uma discussão mais aprofundada dessa classificação, o que fugiria aos fins deste trabalho, cumpre observar que no processo decisório da criação da Funpresp os principais embates se deram entre os parlamentares sindicalistas vinculados às centrais de partidarismo orgânico: CUT/ PT, de um lado; CTB/PCdoB e Intersindical/Psol, do outro. Por sua vez, os parlamentares sindicalistas vinculados às centrais de partidarismo inorgânico, como a FS, tiveram uma participação menos ativa no debate legislativo da criação da previdência complementar dos servidores públicos federais.

Em síntese, de um lado observa-se a disciplina dos parlamentares sindicalistas vinculado à CUT em relação à orientação da liderança do PT; de outro, a crítica dos parlamentares sindicalistas vinculados ao PCdoB e ao Psol ao projeto petista de criação da previdência complementar dos servidores públicos federais. Neste ponto, é digno de nota que, se de um lado o Psol era o principal opositor à esquerda do governo do PT, do outro o PCdoB era parte da base governista.

Assim, ainda que não seja objeto deste trabalho, a vinculação político partidária das centrais sindicais também é um elemento a ser levado em consideração no comportamento dos parlamentares sindicalistas no interior do Congresso Nacional. Nessa perspectiva, o apoio do setor majoritário da bancada parlamentar cutista à criação da Funpresp pode ser analisado a partir da estreita relação da CUT com o PT. ${ }^{10}$ Da mesma forma, a forte oposição dos parlamentares sindicalistas vinculados à Intersindical pode ser compreendida a partir da relação dessa central com o Psol, legenda que surgiu como dissidência do PT justamente durante a reforma da previdência do governo Lula. Por fim, os parlamentares vinculados à CTB, ainda que fizessem parte da base do governo, possuíam uma maior liberdade para fazer críticas ao projeto governista, haja vista que a liderança do PCdoB decidiu liberar a bancada nas principais votaçóes da Funpresp.

Desde a eleição do presidente Lula, a bancada sindicalista no Congresso Nacional tem apresentado importantes oscilaçóes. Em 2002, foram eleitos 74 parlamentares sindicalistas (69 deputados e cinco senadores). Em 2006, a bancada sindical caiu para 61 legisladores (54 deputados e sete senadores). Em 2011, no primeiro mandato da presidente Dilma Rousseff, a bancada sindical voltou a crescer: 91 parlamentares (83 deputados e oito senadores).

Em termos de composição partidária, na 54a Legislatura, os deputados sindicalistas integravam treze partidos. Na Câmara dos Deputados, a maioria absoluta estava na base de apoio do governo: 54 parlamentares no PT, oito no PCdoB, cinco no PDT, três no PV, três no PSB, dois no PMDB, dois no PPS, um no PR, um no PRB, um no PRP, um no PSDB, um no PTdoB e um no Psol. No Senado, eram oito parlamentares: quatro no PT, dois no Psol e dois no PCdoB. Com exceção do PSDB, do Psol e do PPS, todos os demais partidos integravam a base ampliada do governo no Congresso Nacional. Tal composição era um forte indicador de que a maioria dos deputados sindicalistas deveria seguir a orientação do Executivo na votação da criação da Funpresp.

No que se refere à composição profissional dos deputados sindicalistas, a maioria era originária de carreiras vinculadas ao regime geral de previdência (celetistas e profissionais liberais): nove trabalhadores rurais, nove metalúrgicos, seis bancários, seis advogados, cinco economistas, dois petroleiros, dois comerciários, dois engenheiros, dois tecnólogos, um químico, um geógrafo e um ator. Entre os sindicalistas vinculados às carreiras tradicionais do serviço público (estatutários), havia: dezesseis pro- 
Tabela 1

Número de Sindicalistas por Partido Político (Câmara e Senado, 2011)

\begin{tabular}{llll}
\hline Partido & Câmara & Senado & Total \\
\hline PT & 54 & 4 & 58 \\
\hline PCdoB & 8 & 2 & 10 \\
\hline PDT & 5 & 0 & 5 \\
\hline PSB & 3 & 0 & 3 \\
\hline PV & 3 & 0 & 3 \\
\hline PMDB & 2 & 0 & 2 \\
\hline PPS & 2 & 0 & 2 \\
\hline Psol & 1 & 2 & 3 \\
\hline PSDB & 1 & 0 & 1 \\
\hline PRP & 1 & 0 & 1 \\
\hline PRB & 1 & 0 & 1 \\
\hline PR & 1 & 0 & 1 \\
\hline PTdoB & 1 & 0 & 1 \\
\hline Total & 83 & 8 & 91 \\
\hline
\end{tabular}

Fonte: Elaboração própria com base em Diap (2011).

fessores, onze servidores públicos e dez médicos. ${ }^{11}$ No Senado, a bancada sindical tinha a seguinte composição: dois professores, dois bancários, um metalúrgico, um servidor público, um farmacêutico e um técnico em telecomunicaçóes.

A expressiva presença de deputados e senadores vinculados aos trabalhadores do setor privado na bancada sindical (67\%) era outro indicador importante de que a resistência à criação da Funpresp entre os parlamentares sindicalistas não seria predominante, haja vista que esse tema interessava essencialmente os servidores públicos federais.

Em resumo, tanto no que se refere à composição partidária - maioria dos parlamentares da bancada sindical na base governista - quanto à composição profissional - maioria dos representantes sindicais oriundos do setor privado - estava sinalizado que o governo de Dilma Rousseff não encontraria grande resistência entre os deputados e senadores sindicalistas para aprovar o PL de criação da previdência complementar dos servidores públicos federais.

\section{O discurso sindical}

As tensôes e ambiguidades na relação sindicalismo e governo na chamada Era Lula foram objeto de importantes pesquisas e reflexóes no meio acadêmico. ${ }^{12}$ De um lado, não foram poucas as expectativas criadas em torno de um governo que, nas palavras de Cardoso (2015, p. 503) cumpriu a "profecia varguista" de que um dia os trabalhadores governariam. De outro, não foram igualmente poucas as frustaçôes com a continuidade de políticas econômicas e sociais consideradas "conservadoras", como era o caso da própria reforma da previdência (Singer e Loureiro, 2016; Singer, 2012).

Antunes e Silva (2015) observam que a condução e o aprofundamento das políticas adotadas pelo governo FHC, de um lado, e a influência e o controle sobre os movimentos sociais e sindicais, de outro, constituem elementos de fundamental importância para se compreender as dificuldades que setores mais à esquerda do sindicalismo brasileiro com significativa expressão entre as entidades representativas dos servidores públicos, diga-se de passagem - encontraram para resistir às açóes e políticas do governo Lula.

$\mathrm{Na}$ mesma linha de argumentação, Boito Jr. e Marcelino (2010, p. 336) observam que embora o sindicalismo tenha se conformado como um ator político importante na sustentação do governo petista, ele se posicionou como uma força subalterna no arranjo de poder vigente no país, o qual privilegiou fundamentalmente os interesses da "grande burguesia interna brasileira”. Em larga medida, essa análise pode ser igualmente estendida para o governo Dilma, no qual a relação entre sindicalismo e governo continuou marcada por tensóes e ambiguidades herdadas da Era Lula (Cilla e Jard da Silva, 2015).

Assim como ocorreu no debate político e social mais abrangente, a bancada sindical também se dividiu na discussão legislativa sobre a criação da Funpresp. No que se refere ao discurso sindical sobre o tema, podemos identificar três grandes grupos: 1) aqueles que se manifestaram favoravelmente à criação do fundo de previdência complementar dos servidores públicos; 2) aqueles que se manifestaram contrariamente à criação do fundo de previdência complementar dos servidores públicos; 3) 
aqueles que não se manifestaram no debate legislativo da Funpresp.

No que se refere aos deputados sindicalistas com maior destaque no debate legislativo, identificamos entre os contrários à criação da previdência complementar dos servidores: Alice Portugal (PCdoB/BA), André Figueiredo (PDT/CE), João Dado (PDT/SP), Ivan Valente (Psol/SP), Paulo Santiago (PDT/ $\mathrm{PE}$ ). Em termos partidários, na base de apoio ao governo, os deputados sindicalistas filiados ao PDT foram os que apresentaram maior coesão e resistência à aprovação do projeto do Executivo.

Inversamente, no que se refere aos deputados favoráveis à criação do regime complementar dos servidores públicos federais, os mais ativos no debate legislativo foram: Jesus Rodrigues (PT/PI), Rogério Carvalho (PT/SE), Candido Vaccarezza (PT/ $\mathrm{SP})$ e Ricardo Berzoini (PT/S). Destaca-se, nesse caso, corroborando a tese da predominância partidária no comportamento entre os parlamentares sindicalistas, o fato de os deputados mais ativos na defesa da criação da Funpresp serem todos filiados ao PT, principal partido da base governista.

O protagonismo dos deputados petistas na defesa do projeto de criação da Funpresp é particularmente importante se consideramos que historicamente o funcionalismo público constituiu uma das principais bases sociais do PT (Azevedo, 1995; Keck, 1991; Meneguello, 1989). Em outras palavras, entre as pressóes contrárias de setores da sua base social - notadamente dos servidores públicos federais - e a orientação favorável da coalização partidária da qual faziam parte, os parlamentares sindicalistas vinculados ao PT foram fiéis à orientação partidária.

Nesta seção do trabalho, reproduzimos o debate entre os grupos mais ativos de sindicalistas favoráveis e contrários à criação da previdência complementar dos servidores públicos federais. Embora o grupo de deputados sindicalistas que não se manifestou no debate legislativo da matéria fosse maior, ele tendeu a acompanhar os parlamentares alinhados ao governo nas votaçóes.

O Quadro 3 representa as principais categorias de discurso sindical favoráveis e contrárias à criação do regime de previdência complementar dos servidores públicos federais:
Entre as principais críticas à proposta governista, por parte dos parlamentares sindicalistas que se opuseram à criação da Funpresp, destacaram-se: 1) a rejeição do deficit da previdência; 2) a dubiedade da natureza jurídica do novo fundo; 3) a privatização da previdência dos servidores públicos.

No que se refere à primeira crítica, a principal tese era de que o sistema de seguridade social brasileiro - o qual compreende recursos destinados à assistência social, à previdência social e à saúde - não é deficitário. Nessa perspectiva, o conceito de deficit da previdência seria um equívoco. Esse tipo de discurso está bem representado na fala do deputado federal Ivan Valente (Psol/SP): "Não existe deficit da previdência social. $\mathrm{O}$ orçamento da seguridade social é superavitário no nosso país, deputado Berzoini (PT/SP). Nesse orçamento não há deficit do setor público nem do setor privado. $\mathrm{O}$ orçamento da seguridade social é formado por contribuiçóes como a Cofins, a CSLL, as contribuições dos servidores e outras contribuiçóes" (Câmara dos Deputados, Plenário, 14 dez. 2011).

Outra questão central levantada pelos parlamentares sindicalistas contrários à criação da Funpresp referia-se à natureza jurídica do novo fundo de previdência complementar. Segundo os sindicalistas opositores do projeto do governo, a dubiedade na definição da natureza do novo fundo, por se tratar de uma fundação pública de direito privado, criaria uma grande insegurança entre os servidores públicos federais. Essa preocupação ficou expressa no discurso do deputado André Figueiredo (PDT/CE):

Como podemos colocar um fundo voltado ao servidor público, um fundo constitucional, e dar a ele personalidade jurídica de direito privado, fazer com que, na composição desse fundo, possamos ter carteiras administradas por instituiçóes privadas que vão deixar o servidor público à mercê das oscilaçóes do mercado, das crises econômicas mundiais e, consequentemente, não termos segurança jurídica nenhuma, nem segurança econômica de que esse fundo se viabilizará nos próximos trinta anos? (Câmara dos Deputados, Plenário, 29 fev. 2012) 


\section{Quadro 3}

\section{Principais Categorias do Discurso Sindical no Debate Legislativo da Funpresp}

\section{Contrárias \\ 1. Não há deficit na Previdência. \\ 2. Déficit histórico da seguridade não é culpa dos trabalhadores. \\ 3. O projeto vai quebrar a previdência solidária. \\ 4. Entrega ao setor financeiro a contribuição do servidor público.}

5. Não há garantias de recebimento nem de gerência pública.

6. A votação do projeto não deve ser apressada.

7. Inconstitucionalidade, inadequação financeira e orçamentária do projeto.

8. O fundo vai gerar deficit e aumentará o custeio do governo.

9. Melhores profissionais irão para o serviço privado.

10. O fundo ficará em risco com as oscilações do mercado.

11. O fundo deveria ter "natureza pública" para atender interesses públicos.

12. Definir a corresponsabilidade do Estado e instituições financeiras.

13. O servidor vai saber o quanto vai pagar, mas não quanto vai receber.

14. O projeto tira direitos previdenciários dos servidores.

15. Equiparação do RPPS com o RGPS não é benéfica.

\section{Favoráveis}

16. O deficit da previdência existe, a previdência precisa ser sustentável.

17. Não haverá prejuízo aos direitos adquiridos dos servidores.

18. A Funpresp trará segurança para que não se reduza as aposentadorias no futuro.

19. O fundo será uma entidade de natureza pública, sem fins lucrativos, e de direito privado.

20. A transparência e a fiscalização serão garantidas pelo controle dos participantes.

21. O texto legal do projeto foi melhorado.

22. Vai possibilitar uma aposentadoria maior aos servidores.

23. Essa proposta é positiva para os novos funcionários públicos.

24. O novo sistema de capitalização não terá qualquer vínculo com a União.

25. Equaliza de forma mais justa homens, mulheres e inativos.

26. O mérito social do projeto está acima das questôes ideológicas.

27. Superaçáo de uma previdência orçamentária em que o ônus fica para o povo.

Fonte: Elaboração própria com base em Câmara dos Deputados; Diário Oficial.

Por fim, os parlamentares sindicalistas que se opuseram à criação da Funpresp também criticaram veementemente a chamada "privatização" do regime de previdência dos servidores públicos federais, tal como expresso no discurso da deputada Alice Portugal (PCdoB/BA):

O que se está propondo nesse Projeto de Lei é, lamentavelmente, furar a caixa solidária, é, na verdade, entregar ao setor financeiro a capitalização da contribuição do servidor público que entrará a partir dos novos concursos, e ao final não se sabe se há garantia de recebimento. Ainda muito jovem, presidente [deputado Inocêncio Oliveira, PR/PE], eu vi GBOEX, APUB e CAPEMI entregarem moedas aos servidores depois de anos de contribuição. Não há garantias de que essa caixa seja pública, de que a gerência seja pública (Câmara dos Deputados, Comissão Geral, 7 dez. 2011).

Já entre os deputados sindicalistas favoráveis à criação da Funpresp predominou o discurso da promoção do equilíbrio das contas públicas, da re- 
jeição da tese da privatização da previdência e da garantia dos direitos previdenciários dos servidores. Os defensores da criação do regime próprio de previdência complementar dos servidores públicos federais ressaltaram ainda a importância do novo fundo na promoção do desenvolvimento econômico e social do país. Isso é exemplificado na intervenção do deputado Rogério Carvalho (PT/SE): "Logo, é inquestionável o mérito social do Projeto de Lei em apreço quando se sabe que a formação de poupança de longo prazo que financie investimentos de longa maturação é estratégica para o desenvolvimento de todo e qualquer país. [...] Os aspectos levantados novamente colacionam mérito social, de maneira que essa Comissão não pode furtar-se a reconhecê-los" (Câmara dos Deputados, Comissão Geral, 14 dez. 2011).

Os deputados sindicalistas favoráveis à criação da Funpresp também ressaltaram a importância da constituição de uma fundaçáo pública de direito privado para gerir os recursos previdenciários dos servidores públicos federais, rejeitando a crítica de que se tratava da privatizaçáo da previdência do servidor público federal. O deputado Ricardo Berzoini (PT/SP), relator da matéria, esteve entre os principais defensores da natureza jurídica privada do novo fundo:

Cito isso pelo seguinte: nós estamos aqui cumprindo a última etapa de um longo debate na sociedade, autorizando o Estado a criar até três entidades fechadas de previdência complementar, de natureza pública, porque criadas por lei, mas de direito privado, para náo engessar a administraçấo. [...] Respeito profundamente os argumentos do deputado André Figueiredo [PDT/CE], mas quero lembrar que o que nós votamos ontem e que é o cerne desse projeto é para assegurar que nós estejamos criando uma entidade de natureza pública, mas, à semelhança dos demais fundos sem fins lucrativos, uma entidade de direito privado (Câmara dos Deputados, Sessão Plenária, 29 fev. 2012).

Por fim, os deputados sindicalistas favoráveis à criação da Funpresp também rebateram a crítica de que o novo regime previdenciário dos servidores públicos prejudicaria as categorias profissionais que contam com regimes diferenciados de aposentadorias e pensóes. É o que registra o discurso do líder do governo na Câmara, deputado Cândido Vacarezza (PT/SP):

Teremos também um fundo de equalização para garantir que as mulheres do Brasil, que têm o direito constitucional de trabalhar cinco anos menos que os homens, quando funcionárias públicas, tenham a equalização, não percam por esse período que não contribuíram. As pessoas que se acidentarem no trabalho e forem aposentadas também vão ter essa complementação; as pessoas que têm trabalhos especiais, aposentadorias especiais, também vão ter essa complementação. Não serão prejudicadas (Câmara dos Deputados, Sessão Extraordinária, 28 fev. 2012).

Muito embora divididos no que se refere tanto ao diagnóstico do regime próprio de previdência social quanto no que se refere às expectativas do regime de previdência complementar, a maioria dos deputados sindicalistas seguiu a orientaçáo da base governista e votou favoravelmente à criação da Funpresp.

Neste ponto, é particularmente importante destacar o papel dos parlamentares sindicalistas alinhados ao Executivo na legitimação da previdência complementar dos servidores públicos federais como alternativa à crise do sistema previdenciário público. De fato, embora um setor minoritário dos deputados sindicalistas tenha se posicionado contra a criação da Funpresp, a grande maioria dos parlamentares vinculados ao movimento sindical se posicionou favorável à proposta e votou junto com a base do governo federal para a criaçáo do regime de previdência complementar dos servidores públicos federais.

\section{$O$ voto sindical}

Embora não possuam poder de veto institucional, os sindicalistas podem legitimar as propostas de reforma dos sistemas previdenciários (Jard da Silva, 2016; Belánd, 2001). Portanto, ainda que ao longo das últimas décadas as entidades sindicais tenham perdido poder de arregimentação de afiliados (Estanque, Costa e Silva, 2015; Ferreira, 2002; Martins Rodrigues 1999; 1998), elas podem desempenhar 
um papel importante no debate das mudanças das políticas públicas. ${ }^{13}$

No Brasil, diversos autores têm chamado a atenção para a participação sindical no processo de formulação de políticas públicas. Ferraz (2014) desenvolveu um minucioso trabalho de levantamento da presença de sindicalistas nos conselhos de políticas públicas e demonstrou que a eventual perda de poder de arregimentação sindical não significa necessariamente perda de poder de influência dos sindicalistas no debate das políticas públicas.

$\mathrm{Na}$ mesma linha de argumentação, Jardim (2013b) e Silva (2014) têm chamado atenção para a crescente importância do papel dos sindicatos na legitimação e gestão dos fundos de pensão entre os trabalhadores do setor público e privado. Em trabalho recente, Jardim e Jard da Silva (2016) identificam os sindicalistas como um dos principais atores sociais na consolidação institucional da previdência complementar no Brasil.

No presente artigo, argumento que as lideranças sindicais foram igualmente importantes no processo decisório de criação da Funpresp. Embora um setor minoritário da bancada sindical tenha se posicionado contrariamente a ela, a grande maioria dos parlamentares sindicalistas se posicionou favoravelmente à criação do novo fundo de pensão, cumprindo um papel de fundamental importância na legitimação do regime de previdência complementar dos servidores públicos federais.

Conforme registrado anteriormente, os sindicatos não possuem poder de veto institucional no processo decisório da reforma da previdência, mas podem, por intermédio da bancada de parlamentares sindicalistas, influenciar o trâmite legislativo da política previdenciária no Congresso Nacional (Jard da Silva, 2007).

Essa estratégia foi utilizada pelas entidades sindicais para explorar a falta de coesão da bancada situacionista no primeiro mandato do governo Cardoso (Jard da Silva, 2013). Entretanto, durante o governo Lula essa influência indireta no processo decisório da reforma ficou condicionada à posição do $\mathrm{PT}$ em relação à reforma da previdência (Jard da Silva, 2016). A localização da bancada sindical no interior da base governista mudou completamente o jogo da reforma em relaçáo ao que havia ocorrido no governo FHC, quando os deputados sindicalistas estavam na oposiçáo.

No governo Dilma, a bancada sindical continuou condicionada à orientação governista no debate legislativo da criação da previdência complementar dos servidores públicos federais. Desde a votação da constitucionalidade da matéria na CCJC até a revisão da matéria no Senado, o Executivo pôde contar com o voto disciplinado dos deputados sindicalistas.

Esse contexto político institucional reduziu o poder de pressão do funcionalismo público no debate legislativo da criação da Funpresp. Ao longo da tramitação do PL n. 1992/2007, deputados vinculados aos partidos de esquerda, que outrora defendiam os interesses do funcionalismo no Congresso Nacional, votaram a favor do projeto encaminhado pelo Executivo juntamente com os deputados vinculados aos partidos de centro e de direita, tradicionais defensores de mudanças mais profundas no regime próprio de previdência dos servidores públicos.

Assim, no que se refere à matemática dos votos, considerando as principais votaçóes do PL n. 1992/2007, o governo Dilma não enfrentou grandes

Tabela 2

Votos Favoráveis à Criação da Funpresp (\%)

\begin{tabular}{llllll}
\hline & $\begin{array}{l}\text { Subemenda } \\
\text { global }\end{array}$ & $\begin{array}{l}\text { DVS - PSDB - } \\
\text { Art. 4 }\end{array}$ & $\begin{array}{l}\text { DVS - PSDB - } \\
\text { Emenda 43 }\end{array}$ & $\begin{array}{l}\text { DVS - DEM - } \\
\text { Emenda 26 }\end{array}$ & Média \\
\hline Base governista & 67,83 & 93,68 & 96,93 & 85,09 & 85,88 \\
\hline Bancada sindical & 66,15 & 97,72 & 98,07 & 88,89 & 87,71 \\
\hline Plenário da Câmara & 70,00 & 84,00 & 83,20 & 70,90 & 77,03 \\
\hline
\end{tabular}

Fonte: Elaboração própria com base em Câmara dos Deputados. 
dificuldades para arregimentar o número de parlamentares necessários para a aprovação da sua proposta nas diferentes instâncias do processo legislativo. Em média, ao longo do processo decisório, o governo contou com $77 \%$ dos votos para aprovar o projeto.

O governo contou com o voto disciplinado da bancada sindical a favor da criação da Funpresp (Tabela 2). Em momentos cruciais da votação do regime próprio de previdência dos servidores públicos federais, a fidelidade da bancada sindical superou a disciplina da própria base aliada. A base governista manteve-se disciplinada com votação média favorável de $85,88 \%$. Nas mesmas votaçóes, a bancada sindical apresentou disciplina média de 87,71\%.

A esperada resistência entre os deputados sindicalistas, pressionados pelas entidades representativas do funcionalismo público contrárias à reforma, não se configurou. A orientação partidária pesou mais do que a pressão corporativa na decisão dos parlamentares de origem sindical. Entre a recomendação do partido e os interesses específicos de um setor importante do sindicalismo brasileiro, prevaleceu a primeira.

Conforme registrei em trabalho anterior (Jard da Silva, 2016), desde o governo Lula, esse "descolamento" dos parlamentares sindicalistas em relação às demandas da sua base de representação social já havia sido notado pelos próprios dirigentes sindicais:

Os parlamentares que vem do movimento sindical não acompanham na totalidade o que pensa a base sindical. Muito pelo contrário, eles se centralizam e são única e exclusivamente as decisóes da bancada que vão nortear e orientar a sua atuação dentro do parlamento [...]. Eles vão até um limite: acompanham, fortalecem, vão para as mobilizaçóes, chamam para o gabinete, fazem visitas, fazem abaixo-assinado; mas no momento em que o líder [da bancada] organiza e dá as diretrizes, aí a atuação é do partido (depoimento de dirigente sindical da CUT concedido a Jard da Silva 2016).

\section{Quadro 4}

\section{Principais Características da Funpresp}

\begin{tabular}{ll}
\hline Característica & Descrição \\
\hline Administração & Instituiçóes autorizadas pela Comissão de Valores Mobiliários (CVM) \\
\hline Patrocinadora & União \\
\hline Participantes & Servidores públicos federais dos poderes Executivo, Judiciário e Legislativo \\
\hline Estrutura Organizacional & Conselho Deliberativo, Conselho Fiscal e Diretoria Executiva \\
\hline Personalidade Jurídica & $\begin{array}{l}\text { Fundação pública com personalidade jurídica de direito privado, gozando de } \\
\text { autonomia administrativa, financeira e gerencial }\end{array}$ \\
\hline Receita & $\begin{array}{l}\text { Oriunda das contribuiçóes dos participantes, assistidos e patrocinadores; dos resultados } \\
\text { financeiros de suas aplicaçóes e doaçôes e legados de qualquer natureza }\end{array}$ \\
\hline Plano de Benefício & Contribuição Definida (CD) \\
\hline Contribuição & $\begin{array}{l}\text { Contribuiçáo do participante: 7,5\%; 8\%; ou 8,5\%. Patrocinador: igual à do } \\
\text { participante, até o limite de 8,5\% }\end{array}$ \\
\hline Investimentos & $\begin{array}{l}\text { Atrelado aos índices de referências do mercado, observando as diretrizes e limites de } \\
\text { prudências estabelecidas pelo Conselho Monetário Nacional (CMN) para as entidades } \\
\text { fechadas de previdência complementar }\end{array}$ \\
\hline Fiscalização & Tesouro Nacional, Banco Central e Ministério do Planejamento \\
\hline
\end{tabular}

Fonte: Elaboração própria com base em Jardim e Jard da Silva (2016). 
$\mathrm{Na}$ votação da criação da Funpresp, dos 65 deputados sindicalistas presentes, $43(66,15 \%)$ votaram a favor e $22(33,85 \%)$ votaram contra. Os votos contrários vieram majoritariamente de deputados que tinham sua trajetória profissional vinculada aos servidores públicos: seis professores, seis servidores públicos e dois médicos. ${ }^{14}$ No entanto, é importante observar que, mesmo entre os deputados originários de categorias vinculados ao funcionalismo público, o governo angariou o apoio de 17 $(54,84 \%)$ dos 31 parlamentares: seis professores, seis médicos e cinco servidores.

Assim, não obstante a resistência dos servidores públicos e das suas entidades representativas (associaçóes e sindicatos), com o apoio da bancada sindicalista e de setores da própria oposição, o governo Dilma aprovou a criação da Funpresp.

O Quadro 4 sintetiza as principais características administrativas, organizacionais e financeiras do novo regime previdenciário dos servidores públicos federais:

Em síntese, os dados analisados nesta pesquisa corroboram a tese da predominância partidária (Arretche, 2012; Figueiredo e Limongi, 1999) mesmo na tramitação de proposiçóes legislativas que afetam negativamente grupos de interesses com representação parlamentar. Como em Jard da Silva (2016), a análise do resultado das votaçóes demonstra que, mesmo entre os parlamentares vinculados às categorias profissionais do setor público, prevaleceu a orientação da bancada partidária em detrimento das demandas específicas do funcionalismo.

A bancada sindical votou de forma disciplinada a favor da proposta do Executivo, seguindo a orientação da liderança partidária. Paradoxalmente, tal como ocorrera no governo Lula, os parlamentares sindicalistas tiveram ao seu lado antigos adversários políticos - do PSDB e do DEM - históricos defensores de reformas mais profundas na previdência social.

\section{Consideraçôes finais}

O presente artigo teve como inspiração teórica e metodológica os seguintes questionamentos: em situaçóes político-institucionais em que um gover- no considerado aliado envia ao Congresso Nacional projetos que contrariam interesses de importante setores do movimento sindical, qual é a posição predominante no bloco sindicalista? Defender as demandas das suas bases de representação social ou seguir a orientação do partido e/ou coalizão partidária da qual faz parte?

Diante dessas duas questôes, pelo menos duas possíveis respostas se apresentam: 1) os parlamentares eleitos com apoio dos sindicatos se opóe às iniciativas que implicam perdas ao seu reduto eleitoral; 2) os deputados sindicalistas seguem a orientação partidária em detrimento das demandas de sua base de representação social.

O problema de pesquisa foi abordado a partir da análise da participação da bancada sindical no processo decisório da criação da Funpresp, liderado pelo PT durante o primeiro mandato de Dilma Rousseff.

Desde a redemocratização do país, o movimento sindical tem investido recursos humanos e materiais no apoio de candidaturas de políticos considerados aliados dos trabalhadores, notadamente sindicalistas e ex-sindicalistas. Os achados dessa pesquisa confirmam a importância dessas candidaturas e do ativismo legislativo da bancada sindical, mas ressalvam que o alinhamento dos parlamentares eleitos às demandas da sua base de representação social não é automático.

Regras formais e informais de tomada decisão condicionam o comportamento da bancada sindical no interior do Congresso Nacional. Em situaçôes político-institucionais em que há divergência entre a orientação da coalização partidária do qual fazem parte e os interesses da base sindical, os parlamentares sindicalistas tendem a seguir a orientação do partido.

No caso específico do presente trabalho, as características político-institucionais do presidencialismo de coalizão brasileiro restringiram as possibilidades de influencia dos grupos de interesse no trâmite legislativo PL n. 1992/2007. Em outras palavras, a fidelidade dos deputados sindicalistas à orientação partidária limitou o poder de resistência do funcionalismo público e de suas entidades representativas no processo decisório da criação da Funpresp.

Assim como ocorrera nos dois mandatos do presidente Luiz Inácio Lula da Silva (2003-2010), 
no primeiro mandato da presidente Dilma Rousseff (2011-2014) a bancada sindical era parte da base de sustentação do governo no Congresso Nacional. $\mathrm{E}$, entre as pressóes contrárias do funcionalismo público e a orientação partidária favorável à criação da Funpresp, os parlamentares sindicalistas seguiram esta última.

Em resumo, os dados apresentados neste artigo corroboram a tese da predominância partidária, mesmo diante da resistência de poderosos grupos de interesses, notadamente os servidores públicos federais e suas entidades representativas. Entre a pressão da base contrária à criação da Funpresp e a orientação governista favorável à criação da previdência complementar dos servidores públicos federais, a maioria dos parlamentares sindicalistas, inclusive os originários do setor público, seguiu a orientação da coalizão partidária e votou com o governo.

\section{Notas}

1 Valiosas exceçôes são as análises realizadas por Rodrigues (2009a; 2009b: 2002), Rodrigues e Sadek (2010) e Aragão (1996).

2 Sobre o sistema de comissóes no Legislativo brasileiro, ver também Rocha e Barbosa (2012), Ricci e Lemos (2004) e Santos (2002).

3 Sobre a distinção entre "coesão" e "disciplina", ver Tsebelis (1997, p. 103).

4 Essa seção adota como referência metodológica a pioneira análise do processo decisório da reforma da previdência realizado por Figueiredo e Limongi (1998).

5 Sobre os custos de transição de um regime de repartição de benefício definido para um regime de capitalização de contribuição definida, ver Mesa-Lago (2002) e Orszag e Stiglitz (2001).

6 Sobre o papel "autorregulador" do Senado Federal no Legislativo brasileiro, ver Ricci (2003, p. 718).

7 Conforme Ricci (2003, p. 721): “A participação dos líderes no processo decisório, por meio do pedido de urgência, e o interesse de um grupo de parlamentares, via apresentação de requerimento de inclusão na ordem do dia, são fatores que têm peso relativo considerável na tramitação dos projetos bem-sucedidos”.

8 Gurza Lavalle, Houtzager e Castello (2006, p. 44) observam que "o apoio fornecido por organizaçóes civis a candidatos políticos é, de longe, a variável com capa- cidade de predição mais acurada da propensão dessas organizaçóes civis a assumir o caráter de representantes dos seus beneficiários”.

9 Classificação semelhante pode ser encontrada em Cardoso e Gindin (2017, p. 31), quando se referem à CUT e à CTB como "base social orgânica de um projeto político de poder" e à FS como “aliada circunstancial e pragmática”.

10 Cardoso e Gindin (2017, p. 22) também observam que a relação orgânica entre a CUT e o PT se converteu em "participação orgânica" do sindicalismo no governo Lula.

11 Um minucioso estudo sobre o perfil político e social dos deputados federais oriundos do serviço público, entre 1982 e 2010, pode ser encontrado em Codato, Ferreira e Costa (2015). Sobre as particularidades da inclinação dos servidores públicos brasileiros à carreira política, ver Santos (1997).

12 Consultar, por exemplo, as coletâneas organizadas por Oliveira, Bridi e Ferraz (2014) e Singer e Loureiro (2016). Ver também o dossiê coordenado por Santana (2015).

13 Para uma revisão crítica sobre o sindicalismo brasileiro nas últimas décadas, ver Antunes e Silva (2015), Ramalho (2011), Santana e Braga (2009) e Bridi (2006). Sobre o sindicalismo internacional, ver Bautista (2010), Estanque (2011; 2009), Hyman (2002), Ferreira (2002) e Murillo (2001).

14 Os demais votos contrários foram de dois metalúrgicos, dois bancários, um comerciário, um advogado, um economista e um ator.

\section{BIBLIOGRAFIA}

AGENNCIA BRASIL. (2012), "Novo modelo de previdência não dá a servidor garantia sobre valor de aposentadoria, diz Condsef". Agência Brasil, 29 mar.

ANTUNES, Ricardo \& SILVA, Jair Batista da. (2015), "Para onde foram os sindicatos? Do sindicalismo de confronto ao sindicalismo negocial”. Caderno CRH, 28 (75): 511-527. Disponível em dx.doi.org/10.1590/S010349792015000300005 , consultado em 6/6/2016. ARRETCHE, Marta. (2012), Democracia, federalismo e centralizaçáo no Brasil. Rio de Janeiro, Editora FGV/Editora Fiocruz. 
ARAGÃO, Murillo de. (1996), "A ação dos grupos de pressão nos processos constitucionais recentes no Brasil". Revista de Sociologia e Politica, 6 (7): 149-165.

ARNOLD, Douglas. (1998), "The politics of reforming social security". Political Science Quarterly, 113 (2): 213-240.

ARNOLD, Douglas. (1990), The logic of congressional action. New Haven (CT), Yale University Press.

BAUTISTA, Lucca J. (2010), "Estudio comparado sobre la centralidad del trabajo y el sindicalismo en el discurso identitario de Lula da Silva (2003-2006) y Nestor Kirchner (2003-2007)". $V$ Congreso Latinoamericano de Ciencia Política. Buenos Aires, 28-30 jul.

BÉLAND, Daniel. (2001), "Does labor matter? Institutions, labor unions and pension reform in France and the United States". Journal of Public Policy, 21 (2): 153-172.

BOITO JR., Armando \& MARCELINO, Paula. (2010), "O sindicalismo deixou a crise para trás? Um novo ciclo de greves na década de 2000". Caderno CRH, 23 (59): 323-338.

BRIDI, Maria A. (2006), "As várias manifestaçóes de crises no sindicalismo e a crítica ao pensamento generalizante de crise", in S. M. de Araújo, M. A. Bridi e M. Ferraz (orgs.), $O$ sindicalismo equilibrista, Curitiba, UFPR/ SCHLA.

CARDOSO, Adalberto Moreira. (2015), "Dimensóes da crise do sindicalismo brasileiro". Caderno CRH, 28 (75): 493510. Disponível em dx.doi.org/10.1590/ S0103-49792015000300004, consultado em 6/6/2016.

CARDOSO, Adalberto \& GINDIN, Julián. (2017), "O movimento sindical na Argentina e no Brasil (2002-2014)". Sociedade e Estado, 32 (1): 13-37.

CILLA, Karen. C. D. F. \& JARD DA SILVA, Sidney. (2015), "Sindicalismo e políticas públicas: análise do discurso da CUT nos governos FHC, Lula e Dilma”. Idéias - Revista do Instituto de Filosofia e Ciências Humanas da Unicamp, 6: 101-133.

CODATO, Adriano; FERREIRA, Ana P. L. \& COSTA, Luiz D. (2015), "Do serviço público à Câmara dos Deputados: os parlamentares originários do funcionalismo público no Brasil”. Revista do Serviço Público, 66 (4): 605-626.

COSTA, Hermes Augusto. (2011), "Do enquadramento teórico do sindicalismo às respostas pragmáticas", in E. Estanque e $\mathrm{H}$. A. Costa (orgs.), O sindicalismo português e a nova questão social: crise ou renovação? Coimbra, Almedina.

DIAP - Departamento Intersindical de Assessoria Parlamentar. (2002), Série Estudos Políticos. Brasília, Diap.

DIAP - Departamento Intersindical de Assessoria Parlamentar. (2011), "Novo levantamento mostra ampliação da bancada sindical no Congresso". Brasília, Diap. Disponível em www. diap.org.br/ -diap/index.php/noticias/agencia-diap/16573-novo-levantamento-mostra-ampliacao-da-bancada-sindical-no-congresso, consultado em 1/3/2018.

DINIZ, Simone. (1999), "Processo legislativo e sistema de comissóes". Revista do Legislativo, 26: 59-78.

ESTANQUE, Elísio. (2011), "Trabalho, sindicalismo e ação colectiva: desafios no contexto de crise", in E. Estanque e H. A. Costa (orgs.), O sindicalismo português e a nova questão social: crise ou renovação? Coimbra, Almedina.

ESTANQUE, Elísio. (2009), "Precariedade, sindicalismo e acção colectiva", in FERVE e APRE (orgs.), Dois anos a FERVEr: retratos da luta, balanço da precariedade, Porto, Afrontamento/ FERVE/APRE.

ESTANQUE, Elísio; COSTA, Hermes Augusto \& SILVA, Manuel Carvalho da. (2015), "O futuro do sindicalismo na representação sociopolítica", in A. Freire (org.), O futuro da representação politica democrática, Lisboa, Nova Vega.

FERRAZ, Alexandre Sampaio. (2014), "Novos rumos do sindicalismo no Brasil". Revista Brasileira de Ciências Sociais, 29 (86): 109-123.

FERREIRA, Virgínia. (2002), "O efeito Salieri: o sindicalismo perante as desigualdades entre mulheres e homens no emprego". Revista Critica de Ciências Sociais, 62: 121-147.

FIGUEIREDO, Argelina Cheibub \& LIMONGI, Fernando. (1996), "Congresso Nacional: 
Organização, Processo Legislativo e Produção Legal". Cadernos de Pesquisa, 5.

FIGUEIREDO, Argelina Cheibub \& LIMONGI, Fernando. (1998), "Reforma da previdência e instituiçóes políticas". Novos Estudos, 51: 63-90. FIGUEIREDO, Argelina Cheibub \& LIMONGI, Fernando. (1999), Executivo e Legislativo na nova ordem constitucional. Rio de Janeiro, Editora FGV.

HYMAN, Richard. (2002), "The future of unions". Just Labour, 1: 7-15.

GRUN, Roberto. (2005), “O 'nó' dos fundos de pensão”. Novos Estudos - Cebrap, 73: 19-31.

GRUN, Roberto. (2003), "Fundos de pensão no Brasil do final do século XX: guerra cultural, modelos de capitalismo e os destinos das classes médias". Revista Mana, 9 (2): 7-38.

GURZA LAVALLE, Adrián G.; HOUTZAGER, Peter P. \& CASTELLO, Graziela. (2006), "Representação política e organizaçóes civis: novas instâncias de mediação e os desafios da legitimidade". Revista Brasileira de Ciências Sociais, 21 (60): 43-66. Disponível em dx.doi. org/10.1590/S0102-69092006000100003, consultado em 18/6/2017.

IMMERGUT, Ellen. (1996), "As regras do jogo: a lógica da política de saúde na França, na Suíça e na Suécia”. Revista Brasileira de Ciências Sociais, 30 (11): 139-165.

JÁCOME RODRIGUES, Iram. (1999), O novo sindicalismo: 20 anos depois. Petrópolis (RJ), Vozes.

JÁCOME RODRIGUES, Iram. (2015), “Trabalhadores e sindicalismo no brasil: para onde foram os sindicatos?". Caderno CRH, 28 (75): 479491. Disponível em dx.doi.org/10.1590/S010349792015000300003 , consultado em 6/6/2016.

JARD DA SILVA, Sidney. (2007), Reforma da previdência em perspectiva comparada: executivo, legislativo e sindicatos na Argentina e no Brasil. São Paulo, Humanitas.

JARD DA SILVA, Sidney. (2013), Companheiros servidores: o sindicalismo do setor público na CUT. Santo André (SP), UFABC/Fino Traço.

JARD DA SILVA, Sidney. (2016), "Unionism, decision-making process and social security reform in Brazil”. Brazilian Political Science Review, 10: 2. Disponível em www.scielo.br/pdf/bpsr/v10n2/1981-3821bpsr-10-2-1981-38212016000200002.pdf, consultado em 2/3/2018.

JARD DA SILVA, Sidney \& DINIZ, Simone. (2009), "Reforma previsional, sindicalismo y proceso de toma de decisiones en Argentina y en Brasil". Documentos y Aportes en Administración Pública y Gestión Estatal, 9: 31-58.

JARDIM, Maria C. (2013a). "A crise financeira de 2008: os discursos e as estratégias do governo e dos fundos de pensão". Dados, 56 (4): 901-941.

JARDIM, Maria C. (2013b), Entre solidarite et risque: syndicats et fonds de pension durant sous le gouvernement Lula. Paris, L'Harmattan.

JARDIM, Maria. A. C. \& JARD DA SILVA, Sidney. (2016), "Difusão da previdência complementar no Estado brasileiro: dos fundos de empresa pública à criação da Funpresp", in C. A. P. de Faria, D. Bandeira e S. Jard da Silva (orgs.), Difusão de políticas públicas, São Bernardo do Campo (SP), EdUFABC.

MACHADO RODRIGUES, Theófilo C. (2015), "Centrais sindicais e partidos políticos no Brasil”. XVII Congresso Brasileiro de Sociologia. Porto Alegre, 20-23 jul.

MARTINS RODRIGUES, Leôncio. (1998), "O declínio das taxas de sindicalização: a década de 80. Revista Brasileira de Ciências Sociais, 13, (36). Disponível em www.scielo.br/scielo.php?script $=$ sci_arttext $\&$ pid $=$ S0102-69091998000 $100003 \& \operatorname{lng}=$ pt\&nrm=iso, consultado em $10 / 11 / 2017$.

MARTINS RODRIGUES, Leôncio. (1999), Destino do sindicalismo. São Paulo, Edusp.

MARTINS RODRIGUES, Leôncio. (2002), "Partidos, ideologia e composição social". Revista Brasileira de Ciências Sociais, 1748: 31-47. Disponível em dx.doi.org/10.1590/ S0102-69092002000100004, consultado em 30/1/2016.

MARTINS RODRIGUES, Leôncio. (2009a), Mudanças na classe politica brasileira. Rio de Janeiro: Centro Edelstein de Pesquisas Sociais. Disponível em static.scielo.org/scielobooks/ h6kh6/pdf/rodrigues-9788579820113.pdf, consultado em 14/6/2015. 
MARTINS RODRIGUES, Leôncio. (2009b), Partidos, ideologia e composição social: um estudo das bancadas partidárias na Câmara dos Deputados. Rio de Janeiro, Centro Edelstein de Pesquisas Sociais. Disponível em static.scielo.org/scielobooks/9yf86/pdf/rodrigues-9788579820250. pdf, consultado em 14/6/2015.

MARTINS RODRIGUES, Leôncio \& SADEK, Maria T. A. (2010), El Brasil de Lula: diputados y magistrados. Rio de Janeiro, Centro Edelstein de Pesquisas Sociais. Disponível em static.scielo.org/scielobooks/ctdh3/pdf/rodrigues-9788579820359.pdf, consultado em $14 / 6 / 2015$.

MELO, Carlos Ranulfo \& ANASTASIA, Fátima. (2006), "Social security reform in two stages". Dados, 2. Disponível em socialsciences.scielo.org/scielo.php?pi$\mathrm{d}=$ S0011-52582006000200005\&script=sci_ arttext, consultado em 24/3/2015.

MESA-LAGO, Carmelo. (2002), "Myth and reality of pension reform: the Latin America evidence". World Development, 30 (8): 1309-1321.

MURILLO, Maria V. (2001), Labor unions, partisan coalitions, and market reforms in Latina America. Cambridge (MA), Cambridge University Press.

NORONHA, Eduardo. (1999), Entre a lei e a arbitrariedade: mercados e relaçôes de trabalho no Brasil. São Paulo, LTr.

OLIVEIRA, Roberto V. de; BRIDI, Maria A. \& FERRAZ, Marcos. (2014), O sindicalismo na era Lula: paradoxos, perspectivas e olhares, Belo Horizonte, Fino Traço.

PALERMO, Vicente. (2016), "Brazilian political institutions: an inconclusive debate". Brazilian Political Science Review, 10 (2): e0003. Disponível em dx.doi.org/10.1590/198138212016000200003 , consultado em $17 / 5 / 2017$.

PALERMO, Vicente. (2000), "Como se governa o Brasil? $\mathrm{O}$ debate sobre instituiçōes políticas e gestáo de governo". Dados, 43 (3): 521-557. Disponível em dx.doi.org/10.1590/ S0011-52582000000300004, consultado em 18/6/2017.

ORSZAG, Peter \& STIGLITZ, Joseph E. (2001), Rethinking pension reform: ten myths about social security: toward sustainable pension system in the 21st Century. Washington, The World Bank.

PIERSON, Paul. (1997), Dismantling the welfare state? Reagan, Thatcher, and the politics of retrenchment. Cambridge (MA), Cambridge University Press.

RAMALHO, José R. (2011), "Trabalho e trabalhadores: organização e lutas sociais", in A. Botetho e L. M. Schwarcz (orgs.), Agenda brasileira: temas de uma sociedade em mudança, Sáo Paulo, Companhia das Letras.

RANGEL, Leonardo A. (2013), A criação da previdência complementar dos servidores públicos e a instituição de um teto para os valores dos benefícios: implicaçôes na distribuição de renda e na taxa de reposiçāo das aposentadorias. Tese de doutorado. Rio de Janeiro, UFRJ.

RICCI, Paolo \& LEMOS, Leany Barreiro. (2004), "Produção legislativa e preferências eleitorais na Comissão de Agricultura e Política Rural da Câmara dos Deputados". Revista Brasileira de Ciências Sociais, 19 (55): 107-129.

RICCI, Paolo. (2003), "O conteúdo da produção legislativa brasileira: leis nacionais ou políticas paroquiais?" Dados, 46 (4): 699734. Disponível em dx.doi.org/10.1590/ S0011-52582003000400003, consultado em 26/5/2017.

ROCHA, Marta M. da \& BARBOSA, Cássio F. (2012), "Regras, incentivos e comportamento: as comissóes parlamentares nos países do Cone Sul". Revista de Sociologia e Política, 16 (supl.). Disponível em www.scielo.br/scielo.php?script=sci_arttext\&pid $=$ S0104- $44782008000300007 \&$ lng $=$ pt\&nrm $=\mathrm{i}-$ so, consultado em 29/3/2015.

SANTANA, Marco A. (2015), "Para onde foram os sindicatos?”. Caderno $\mathrm{CRH}, 28$ (75). Disponível em dx.doi.org/10.1590/S010349792015000300001, consultado em 6/6/2016.

SANTANA, Marco A. \& BRAGA, Ruy. (2009), "O pêndulo oscilante: sociologia do trabalho e movimento sindical no Brasil". Caderno CRH, 22 (56): 297-309.

SANTOS, André M. (1997), "Nas fronteiras do campo político: raposas e outsiders no Congresso Nacional". Revista Brasileira de Ciências Sociais, 12, 33: 87-101. 
SANTOS, Fabiano. (2002), "Partidos e comissões no presidencialismo de coalizão". Dados, 45 (2): 237-264. Disponível em www.scielo. $\mathrm{br} /$ scielo.php?script=sci_arttext $\&$ pid=S0011$52582002000200003 \& \operatorname{lng}=$ pt $\& \mathrm{nrm}=\mathrm{iso}$, consultado em 24/3/2015.

SANTOS, Luiz A. (2007), Regulamentação das atividades de lobby e seu impacto sobre as relaçóes entre politicos, burocratas e grupos de interesse no ciclo de políticas púbicas. Tese de doutorado. Brasília, UnB.

SILVA, Rafael Silveira e. (2014), "Beyond Brazilian coalition presidentialism: the appropriation of the Legislative agenda”. Brazilian Political Science Review, 8 (3). Disponível em www. scielo.br/scielo.php?script $=$ sci_arttext $\&$ pi$\mathrm{d}=$ S1981-38212014000300098, consultado em $12 / 1 / 2017$.

SINGER, André. (2012), Os sentidos do lulismo: reforma gradual e pacto conservador. São Paulo, Companhia das Letras.

SINGER, André \& LOUREIRO, Isabel. (2016), As contradiçóes do lulismo: a que ponto chegamos? São Paulo, Boitempo.

SILVA, Sidartha Sória e. (2014), "As relaçôes entre sindicalismo e fundos de pensão no governo Lula", in R. V. de Oliveira, M. A. Bridi e M. Ferraz (orgs.), O sindicalismo na era Lula: paradoxos, perspectivas e olhares, Belo Horizonte, Fino Traço.

TSEBELIS, George. (1997), “Processo decisório em sistemas políticos: veto players no presidencialismo, parlamentarismo, multicameralismo e pluralismo". Revista Brasileira de Ciências Sociais, 12 (34): 89-117.

VISSER, Jelle. (1995), “Trade unions from a comparative perspective”, in J. Van Ruysseveldt, R. Huiskamp e J. Van Hoof (orgs.), Comparative industrial \& employment relations, Londres, Sage. 


\section{BANCADA SINDICAL, POLÍTICA PREVIDENCIÁRIA E PROCESSO DECISÓRIO NO GOVERNO DILMA}

\section{Sidney Jard da Silva}

Palavras-chaves: Sindicalismo; Políticas públicas; Reforma da previdência; Processo decisório; Relaçóes Executivo-Legislativo.

Esse trabalho analisa a participação dos parlamentares sindicalistas (deputados e senadores) no processo decisório de criação da Fundação de Previdência Complementar do Servidor Público Federal (Funpresp), no primeiro mandato do governo Dilma Rousseff (2011-2014). O problema de pesquisa é formulado nos seguintes termos: em condiçôes político-institucionais em que a bancada sindical faz parte da coalizão governista, como se posicionam os parlamentares sindicalistas em matérias que contrariam interesses de setores importantes da sua base de representaçáo social? Os achados da investigação reforçam a tese da predominância partidária no Legislativo brasileiro. A maioria dos legisladores sindicalistas, inclusive os originários do setor público, votou favoravelmente à aprovação do Projeto de Lei n. 1992/2007, que criou a Funpresp, mesmo sob pressão contrária dos servidores públicos federais e de suas entidades representativas.

\section{UNION LEGISLATIVE BLOC, SOCIAL SECURITY POLICY AND DECISION-MAKING PROCESS IN DILMA'S GOVERNMENT}

\section{Sidney Jard da Silva}

Keywords: Unionism; Public policies; Social security reform; Decision-making process; Executive-legislative relations.

This study looks into the participation of unionist parliamentarians in the decision making process for the establishment of the Fundação de Previdência Complementar do Servidor Público Federal, during the first mandate of the Dilma Rousseff government. We formulated the research problem in the following manner: in a political institutional context in which the unionist bloc is part of the government coalition, how do unionist parliamentarians position themselves in law propositions that negatively affect the interests of important parts of their social representative base? The research findings reinforce the thesis of partisan preponderance in the Brazilian decisionmaking process. The majority of unionist parliamentarians, including those originally from the public sector, defended and voted favorably for passing the Bill 1992/2007, which established the Funpresp. This was the case even under strong opposition from federal public servants from the Executive, Legislative, and Judicial branches.

\section{REPRÉSENTATION SYNDICALE, POLITIQUE D'ASSISTANCE SOCIALE ET PROCESSUS DE PRISE DE DÉCISION DANS LE GOUVERNEMENT DILMA ROUSSEFF}

Sidney Jard da Silva

Mots-clés: Syndicalisme; Politiques publiques; Réforme de l'assistance sociale; Processus de prise de décision; Rapports entre les pouvoir exécutif et législatif.

Ce travail analyse la participation des parlementaires syndicalistes (députés et sénateurs) à la décision de création de la Fondation d'assistance sociale complémentaire du fonctionnaire fédéral (Funpresp) pendant le premier mandat du gouvernement Rousseff (20112014). L'objectif était de répondre à la question suivante : dans des conditions politico-institutionnelles où les syndicalistes font partie de la coalition gouvernementale, quelles sont les positions des parlementaires syndicalistes sur des sujets qui contrarient les intérêts de secteurs importants de leur base de représentation sociale ? Les résultats renforcent la thèse de la prédominance partidaire au niveau du pouvoir législatif brésilien. La majorité des législateurs syndicalistes (y compris ceux du secteur public) a voté favorablement pour le Projet de Loi n ${ }^{\circ}$ 1992/2007 approuvant la création de la Funpresp et ce malgré le refus des fonctionnaires et de leurs entités représentatives. 